University of Rhode Island

DigitalCommons@URI

Open Access Master's Theses

1959

\title{
Administration and Transovarial Passage of Radioactive Glycine in the Genus Dermacentor (Acarina: Ixodidae)
}

Joanne L. Hammar

University of Rhode Island

Follow this and additional works at: https://digitalcommons.uri.edu/theses

\section{Recommended Citation}

Hammar, Joanne L., "Administration and Transovarial Passage of Radioactive Glycine in the Genus Dermacentor (Acarina: Ixodidae)" (1959). Open Access Master's Theses. Paper 1494.

https://digitalcommons.uri.edu/theses/1494

This Thesis is brought to you for free and open access by DigitalCommons@URI. It has been accepted for inclusion in Open Access Master's Theses by an authorized administrator of DigitalCommons@URI. For more information, please contact digitalcommons-group@uri.edu. 


\author{
ADMINISTRATION AND TRANSOVARIAL PASSAGE OF \\ RADIOACTIVE GLYCINE IN THE GENUS \\ DERMACENTOR (ACARINA: IXODIDAE) \\ BY \\ JOANNE L. HAMMAR
}

A THESIS SUBMITTED IN RARTIAL FULFILLMENT OF THE REQUIREMENTS FOR THE DEGREE OF

MASTER OF SCIENCE

IN

ZOOLOGY

UNIVERSITY OF RHODE ISLAND

1959 
MASTER OF SCIENCE THESIS

OF

JOANNE L. HAMMAR

Approved:

Major Professor

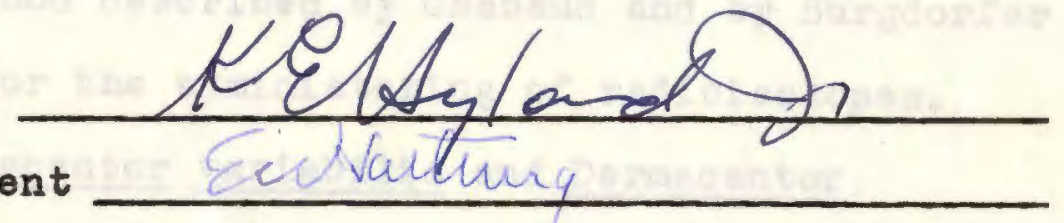

Head of Department

Dean of the College

of Arts and Sciences Daved ofsucusung

Director of Graduate studies $7 x$

UNIVERSITY OF RHODE ISLAND 


\section{ABSTRACT}

The purpose of the investigation is to attermt to make female ticks of the genus Dermacentor radioactive with carbon-14 labeled slycino; to determine whother transovarial passage will take place; and to determine the effect of the 1sotope $\left(\mathrm{C}^{14}\right)$ on the fecundity of the female and on the viability of the eggs.

A feeding method described by Chabaud and by Burgdorfer has been adapted for the administering of radiolsotopes. Female ticks, Dermacentor varlabilis and Dermacentor andersoni, were fed glycine. A micropipette calibrated to hold approximately $0.01 \mathrm{ml}$. of liquid was drawn out and fitted over the hypostome and chelicerae of the tick. The liquid was placed in the tube with a Pasteur pipette and the tick was allowed to $1 \mathrm{mblbe.} \mathrm{After} \mathrm{the} \mathrm{radioactive} \mathrm{meal}$ the females and unfed males were placed in plastic capsules on rabbits for the completion of engorgement. Engorged females were removed and placed in shell vials and allowed to lay their eggs. The number of eggs deposited and the per cent of hatching were determined for each tick. A determination of the level of radioactivity was made for each adult female immediately after her radioactive meal, and after she was removed from the rabbit. The count of radoactivity of eggs and larvae in lots of 200 each from each female was also taken. 
Control individuals of Dermacentor andersoni deposited an average of 6959 eggs of which 5530 (79 per cent) hatched. Radioactive females of Dermacentor andersoni laid an average of 4696 eggs of which 3663 (66.7 per cent) hatched. Females of Dermacentor variabilis produced fower eggs, but hatchability was greater. The control females laid 3108 eggs per tick and 2968 eggs hatched, representing a hatchability of 95.6 per cent. Radioactive ticks produced 2036 eggs, and of these 1916 hatched, resulting in a hatchabllity of 94.8 per cent.

The amount of radioactivity of adult ticks was measured with the Gelger-Muller counter. Lots of ticks that had just finished their radioactive meal had average counts of 222 , 1024, 665, and 1075 per minute. Engorged adults had an average of 286 counts per minute. Using the proportional flow counter, eggs and larvae in lots of 200 gave average counts per minute of 124 (for the eggs) and 57 (for the larvae). Attempts to measure radioactivity of eggs and of larvae with the Gelger-Muller counter were unsuccessful. Statistical tests for slgniflcant differences between untreated and treated individuals revealed no effect of the specific concentrations of $\mathrm{c}^{14}$ gljeine on either eg8 production or hatchability. 
TABLE OF CONTENTS

Page

LIST OF TABLES . . . . . . . . . . . . . v IIST OF ILLUSTRATIONS . . . . . . . . . . v INTRODUCTION .................. I REVIEW OF THE LITERATURE . . . . . . . . . 4 MATERIALS AND METHODS. ............. 11 Choloe of Isotope . . . . . . . . . 11 Preparation of Materials ........ 13 Administering the Isotope .......... 17 Detormination of Radiosctivity. . . . . . 18 Determination of Egg Production and Hatchability ..................... 21 RESULTS. . . . . . . . . . . . . . . 22 DISCUSSION . . . . . . . . . . . 33

Problems in Administering the Isotope .... . 33 Problem of Low Recovers of Ticks . . . . . . 33 Limitations on Number of Engorging Ticks. . . . 34 Difference in Egg Production Between D. variabilis and D. andersoni ............ 34 Analysis of the Data. . . . . . . . . 35 Suggested Uses of the Feoding Technique . . . . 39 Use of the Isotope in the Fleld ....... 40 CONCLUSIONS ....................... 47 
SUMMARY ................ . . 42 ACKNOWLEDGEMENTS. .................... 44 LITERATURE CITED. . . . . . . . . . . . 45 


\section{LIST OF TABLES}

1. Total Number of Female Ticks of the Genus Dermacentor Fed with Control Glyeine and with clt Gljelne, Per Cent Recovery from Host, and Per Cent Total Mortality for Each of Five Groups ... . . . . . . . . . . 23

2. Radioactivity in Counts Per Minuto of Unongorged Females of the Genus Dermacentor Fed with $\mathrm{C}^{14}$ Glycine........

3. Radioactivity in Counts Per Minute of Femeles of the Genus Dermacentor Recovered After Feeding with $\mathrm{C}^{14}$ GIyolne and Engorgement on Host; Radioactivity of Eggs Laid and of Resulting Larvae... . . . . . . . . . . . . . 25

4. Period of Engorgement and Preoviposition Period of Recovered Females, and Inoubation Period of Eggs frgm Ticks of the Genus Dermacentor Fed with $\mathrm{C}^{14}$ Glycine and with Control GIycine . .

5. Eg8 Production and Hatchability Data for Dermacentor andersont Females Fed with Control

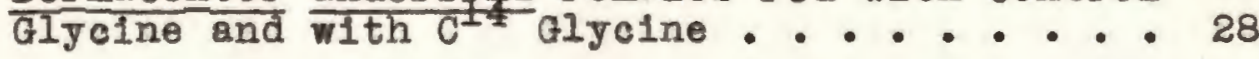

6. Egg Production and HatchabilitJ Data for Dermacentor variabilis Females Fed with Control GIjolne and With C GIJelne... . . . . 29

7: F Values Testing Differences in Variances Between control and Experimental Groups of Dermacentor andersoni and Dermacentor variabilis

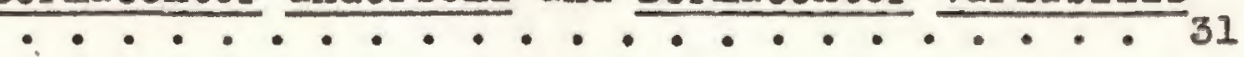

8. " $t$ " Values Testing Differences in Means Between Control and Experimental Groups of Dermacentor andersoni and Dermacentor var1ab111s $\cdot \cdots \cdot \cdot$ 


\section{LIST OF ILLUSTRATIONS}

Figure

Page

18. Rabbit with Capsules for Engorgement of Ticks . - 16

1b. Close-up of Capsule for Engorgement of T1cks

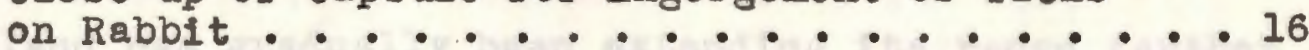

2. Set-up for Feeding $\mathrm{c}^{14}$ Glycine to Female Tleks. . 19 


\section{INTRODUCTION}

The American dog tick, Dermacentor variab1lis (Say), 1821, is abundant along the Atlantic coastline, and in New England has gradually been extending its range farther inland. The adult ticks, which reach their peak of activity In the months of April and May, are found abundantly on a variety of hosts including man. As the summer season approaches there is a marked decline in abundance of adults, and by fall very few are found on the hosts. The Rocky Mountain wood tick, D. andersoni Stiles, 1908 occurs mainly In the Rocky Mountain states and in the Canadian provinces of British Columbia, Alberta, and Saskatchewan.

Of the two ticks, Dermacentor variabilis is the more widely distributed, being found along the eastern and

The name Dermacentor venustus Marx, 1892, has priority over Dermacentor andersoni Stiles, 1908, according to the synonomy of Gregson (1956). He indicates a petition has been submitted to the International Commission on Zoological Nomenclature to suppress the name D. venustus. Nothing has appeared in the avallable literature to confirm this action. However, since the name $\underline{D}$. andersoni has been used extensively, D. venustus will be referred to as D. andersoni. 
western coasts of the United States and somewhat less abundantly inland in the eastern two-thirds of the country. It is also found in Canada, Alaska, Labrador, Moxico, and the Philippine Islands. Both species are known as three-host ticks, and in both sexual dimorphism is marked. The young tick hatches from the egg into the hexapod larval form. The larva attaches to a small mamnal, usually a mouse, feeds upon 1t, detaches, and metamorphoses into an octopod ngruph. Again, the tick finds another host, usually a little larger mammal, upon which to foed. Aftor lmbibing blood it drops from the host and metamorphoses into the adult form. Both sexes attach to hosts again, usually livestock for $\underline{D}$. andersont and preferably dogs in the case of D. variab1118. They then foed and mate on the host. As the female foeds to repletion, her body increases several times in size. Bgg laying begins shortly thereafter and lasts for several weoks, with approximately 5000 eggs being produced.

Individuals of both D. andersoni and D. Variabilis are capable of surviving long periods of starvation. Smith et al. (1946) have shown that adults of D. variab1lis are able to survive from 100 to 1032 days before a blood meal. The larva is less resistant, being able to withstand only 100 to 500 days of starvation.

Relatively little is known about certain aspects of the ocology of D. Variabilis. The present investigation is a pilot study involving the development of a radioactive labeling technique that will aid in the study of the ecology 
of this tick. An attempt has been made to render female ticks radioactive by using glycine labeled with carbon-14, to determine whether transovarial passage of the radioactivity will take place, and to determine the effect of the 1sotope on fecundity of the female and on the viability of the eggs. Female ticks of both Dermacentor variabilis and Dermacentor andersoni were fed approximately $0.01 \mathrm{ml}$. of carbon-14 labeled gljcine by means of a method described by Chabaud and by Burgdorfer. Ticks were placed on a host, allowed to mate, removed from the host and placed in shell vials for oviposition. The level of radioactivity was determined for individual females before they were placed on the host and after they had engorged. The level of radioactivity was also determined for the resulting eggs and larvae in lots of 200 each. Egg production and percentage of hatchability were determined. 


\section{REVIEW OF THE LITERATURE}

Lindqui st (1952), Jenkins (1954), Jenkins and Hassett (1950), Brooks (1956), and others have reviewed the use of radiolsotopes in the fleld of entomology. The use of radio1sotopes has led to greater understanding of host-parasite relationships, dispersion and migration of insects, as well as blological and chemical control of insects. A critical problem involved is that of rendering radioactive the arthropod concerned in the study. In this review attention will be given to the methods of labeling arthropods with radioactive materials and the results obtained therefrom.

The size of insects presents a major difficulty in labeling. It is difficult to inject a fluid into an insect because of the nature of the cuticle and the smaliness of the body. Fuller et 이. (1950) experienced difficulty in inserting cobalt-60 wires into the body cavities of wi reworms and cutworms. The workers postulated that the organs had been plerced or otherwise infured when the wire was inserted because of the high mortality that occurred. Most workers have found that it is easier to incorporate the radioactive substance in the insect's food. With chewing insects this is an easy process, and fairly accurate doses of radioactivity can be administered. Iindsay and Cralg (1942) exposed grain to a radioactive solution of sodium 
dihydrogen phosphate and fed it to mealworms, cockroaches, firebrats, and wax moths. They were able to estimate that two microcuries of phosphorus-32 per gram of body welght were consumed by the insects. It was found that phosphorus- 32 was concentrated most in the epithelium of the mid-intestine, in the gonads, and in the reproductive ducts. Fang and Allen (1955) fed the Douglas-fir beetle a 2.5 per cent glucose solution contalning 2.5 microcurles of phosphorus- 32 per millilter. This proved to be a most satisfactory method because, when washed several times, the beetles lost only two per cent of their radioactivity. Phosphorus-32 was most concentrated in the abdomen and least in the fat bodies. Several investigators found that foeding a radioactive sucrose or milk solution to filies resulted in a good internal label (Jones and Wallace, 1955; Quarterman, et al.; 1954; and Hoffman, et aㅣ., 1951).

Some insects feed on living plant material only. This presents more of a problem in that the 1sotope must be applied to or stored in the proper place in the plant. Root maggot flies were made radioactive by applying phosphorus- 32 to the soll around the roots of turnip plants (Oughton, 1950). Tagging leaf feeders has met with more success. Fuller, Riegert, and Spinks (1954) were able to tag grasshoppers internally with phosphorus- 32 by foeding them leaves of wheat seedlings that had boen dipped in an aqueous solution of phosphorus-32 or that had been sprayed with the same 
solution by means of an atomizer. The nymphs that fed on the wheat seodlings became radioactive. Radioactivity was maintained through adulthood. It was found that there was little loss in radioactivity after the $I_{4}$ th day following the feeding and that loss of radioactivity was negligible through moulting. Another investigator was able to make pineapple mealy bugs radioactive by feeding them on pineapple leaves that had photosynthesized in an atmosphere of $\mathrm{c}^{14} \mathrm{O}_{2}$ (Gray, 1952). The honeydew was subjected to analysis by paper chromatography, and all amino compounds that were not masiced by sugar contained radioactive carbon.

Insects that spend their larval stage in water have boen shown to be very easy to label. Black flles and mosquitoes have been labeled in the larval atage by adding the isotope to the water in which the insects were developing (Bugher and Taylor, 1949; Hassett and Jonkins, 1949; Yates, et al., 1951; Provost, 1952; Fredeen, et aㅡ., 1953; Quarterman, 으 al., 1955; and Bruce-Chwatt and Hayward, 1956). It was found that when phosphorus- 32 was added to the water that the 1sotope was absorbed by the insect in the last larval instar and that very little uptake occurred in the pupal stage. Radioactivity loss was slight through the pupal and adult stages with the exception of egg laying. Adult mosquitoes were made radioactive by allowing them to feed on a rabblt injected with phosphorus-32 (Hassett and Jenkins, 1951) or on rats that had boen injected with the same element (Yates, et a‥, 1951). 
Several investigators have experimented with external labels. Two methods have been used. One is a washing technique and the other is a "gluing" technique. In the first method the insect is dipped into a solution containing the radiolsotope and usually a wetting agent. The solution is allowed to dry on the insect before it is released. The gluing technique involves gluing a radioactive wire or compound onto the insect. Depending on the kind of insect, 1ts mode of locomotion and its level of activity, and its living habits, an external label may be satisfactory. Its use is limited to short-term studies and to studies involving only one stage in the life of the insect. When the insect moults, the label is, of course, lost. One such study is of interest. External labeling of the lone star tick, Amblyomma americanum, was accomplished by means of a washing technique (Knapp, et al., 1956). A radioactive solution of sodium dihydrogen phosphate was poured into a funnel containing one lot of 200 ticles. The solution was removed by applying a vacuum. This was repeated three times. Over 1300 ticks were labeled in this manner. The authors rejected the 1dea of foeding the ticks on a radioactive host. The reasons given were these: 1) the time involved in the feoding of the ticks on a host, 2) the expense of purchasing and caring for laboratory animals, and 3) the disposal of contaminated wastes.

Very little work with insects has been done with carbon-14. Most of this work concerns the effect of 
Insecticides and will not be reviewed here. There are three papers that are of interest. The study on mealy bug honeydew (Gray, 1952) has already boen mentioned. Oertel, 스 al. (1953) investigated the transfer of honey from the worker bees to the drones. Worker bees were given plain sucrose. The results indicated that the drones were radioactive, proving that there had been a transfer between the worker and the drone. Another group of investigators showed that it was possible to give an insect radioactive compounds from which other substances would be manufactured by the body. The glant silkworm, Platysamia cercropia, was in jected with carbon-14 labeled glycine and alanine (Zamecnik et al., 1949). It was ascertained that some of the fibers in the cocoon were radioactive. Chemical tests demonstrated the presence of radioisotopes in the alpha-carboxyl group of cortain amino acids.

One method of feeding blood-sucking arthropods has been mentioned, that of feeding mosquitoes on radioactive animals. Another method involves the use of membranes, usually made of skins of animals (Kartman, 1954). The membrane surrounds a glass tube filled with the desired amount of blood which has been cltrated to prevent clotting. The animal inserts its mouth parts into the membrane and sucks up the blood. A certain temperature must be maintained for the animal to feod. Sometimes difficulty is experienced with this technique since conditions must be exact before feeding will take place. A third method which has been devised recently 
Involves the use of capillary pipettes which are inserted over the mouth parts (Chabaud, 1950; Burgdorfer, 1957).

of these three methods the new one described by Chabaud and by Burgdorfor was selected for use in this investigation. (Seo Methods and Materials.) A fairly accurate dosage was claimed, and there was no problem of disposing of radioactive host animals.

Few investigators have obtained radioactive young from radioactive parents. A few house flles fed on a 10 per cent sugar solution containing phosphorus-32, showed counts of 5000 to 8500 per minute and produced eggs having from five to 32 counts per minute (Hoffman, et 리., 1951). Screw-worm flies reared in a medium containing phosphorus-32 produced radioactive eggs and larvae (Radeleff, et al., 1952). It was noted that radioactivity in counts per minute was almost directly proportional to the concentration of the isotope in the rearing medium. There was little loss in radioactivity from the egg stage to the larval stage. Lawson, et al. (1954) accounted for some of the loss of radioactivity in green peach aphids through excretion, moulting, and giving birth to radioactive joung. The two-spotted apider mite was made radioactive by feeding on bean leaves previously treated with phosphorus-32 (Rodriguez, 1954). Accumulation of phosphorus- 32 in the eggs was found to be three times greater by unit volume than in the adult. Mosquitoes (Anopheles atroparvus) that were reared in a larval bath 
containing radioactive strontium at a concentration of 162 microcuries per $\mathrm{ml}$. produced adults that deposited radioactive eggs (100 eggs $=0.3$ microcurie) that were fertile (Bugher, Taylor and Bruce-Chwatt, 1956). These slightly radioactive larvae developed into normal adults. 
MATERIALS AND METHODS

Before a label can be offectively used on an arthropod in the fleld preliminary laboratory work is desirable. The first problem is to choose the appropriate labeling material. The second problem is to attach the label in some suitable way to the animal, and the third is to attempt to ascertain what effect, if any, the label will have upon the physiology and survival of the animal. Recently the use of radioisotopes has become widely used in the study of animal dispersion. (See Review of the Iiterature.)

Cholce of Isotope

One requirement of this investigation was to choose an Isotope that would be likely to be incorporated into the body tissues of the tick so that internal labeling would be effected. Since much of the tissues of an organism are composed malniy of five elements--oxygen, hydrogen, nitrogen, carbon, and phosphorus--the 1sotop 1c forms of these elements were considered. The isotopes of both oxygen and nitrogen were refected because since they are stable, the use of a mass spectrograph is necessary to detect their presence. This apparatus was not avallable for use in the investigation. Tritium, the commonly used 1sotope of hydrogen, must be detected with a liquid scintillation counter. This instrument was also unavailable, and so the idea of using 
tritium was discarded. Phosphorus-32 was also rejected, but not for lack of proper detection equipment. While phosphorus32 has been an ideal label in many studies (see Review of the Iterature), Its use by an inexperienced investigator was considered unwise. Phosphorus-32 is a hard beta emitter, and lead shielding must be employed when handling. It also has a short half-life of only 14.3 days. Carbon-14 was selected for use in the investigation. This 1sotope is relatively safe to handle. Carbon-ly emits soft beta rays that have little penetrating power. The rays do not penetrate glass so that all material can be easily stored in glass contalners. There are two dangers that can result from careless handling. One danger comes from spilling the isotope or from an explosion. Since the half-life of carbon-14 is approximately 5,500 jears, decontamination of a laboratory can become costly, if it is possible. The other danger comes from accidental ingestion. If the 1sotope becomes incorporated into the body tissues, internal in jury may result (Bugher, 1955). The 1sotope can be detected with the Geiger-Muller counter and the proportional flow counter. These instruments were available to the investigator.

A simple amino acid, glycine, was chosen as the carrier. Relatively little is known about the occurrence of glycine in arthropods. It does not occur in chitin and very little occurs in arthropodin, the water soluble part of the exoskeleton; but 1 t $1 \mathrm{~s}$ known that large amounts occur in egg 
sholls (Richards, 1951). Glycine is also found as a freo amino acid in the hemolgmph of the insect (Buck, 1953). From this information it was postulated that the tick might utilize glycine in tissues and in egg production and that some of the carbon-14 glycine would remain within the body of the tick. An important consideration is that carbon-14 glycine is easy to handle in the laboratory. The chemical is water soluble. If the hands should be contaminated accidentally with the labeled glycine, they can be easily decontaminated by washing the hands in soap and water for several minutes.

Preparation of Materials

Fifty microcuries of glycine-1-carbon-14 were obtained from the Volk Radio-Chemical Company. The glycine weighed $0.89 \mathrm{mg}$. and had a specific activity of 4.2 microcuries per millimole. The glycine therefore contained 11.8 millimoles. The glycine was dissolved in sterile distilled water to make one millilter and placed in a sterile serum bottle with a tight rubber cover. This constituted the stock solution and was not further diluted. Small amounts of the glycine were removed from the serum bottle by means of a hypodermic syringe. Except when in use, the chemical was kept under normal refrigeration temperatures to prevent attack from mola.

The control solution contained the same concentration of glycine. It was also kept under refrigeration. 
Two species of ticks, Dermacentor andersoni and $\underline{D}$. variabilis, were obtained from the Rocky Mountain Laboratory, Hamilton, Montana. The ticks were kept in pill boxes in a malling tube and stored under refrigeration near freezing temperatures. Occasionally a plece of wet cotton was placed in the mailing tube to provide molsture. When the ticks were received from the Rocky Mountain Laboratory, it was certain that the specimens of $\underline{D}$. andersoni would feed because they had been starved for about a year. However, the spec1mens of D. variabilis had just emerged from their nymphal skins and readiness to feed was questioned. Therefore, $\underline{D}$. andersoni was selected first for feoding. When the supply of $\underline{D}$. anderson1 became exhausted, $\underline{D}$. varlab1lis was ut1lized. To prepare the feeding tubes, melting point capillaries, approximately $10 \mathrm{~cm}$. long and one mm. In diameter were washed in the detergent, "Tide", and rinsed several times in tap water, the last time in distilled water. The tubes were then alr-dried and cut in half. Over the flame of an alcohol lamp, the half tubes were drawn to the desired calibre, broken into two equal parts, and the broken ends made even and smooth. The tubes were callbrated by filling them with distilled water and welghing on an angtical balance. Several tubes were calibrated. When the tubes measured one cm. with a diameter of one mm., not including the drawn out part, they held between 0.011 and $0.019 \mathrm{ml}$. of distilled water. The tubes were cut at the one cm. length mark, or were marked at one $\mathrm{cm}$. with a mixture of India ink and 
mucilage. As each tube was prepared, it was fitted over the mouth parts of a tick to be certain that it would fit well. Pasteur plpettes were drawn to a diameter small enough to be inserted inside the prepared foeding tube. Once the foeding tubes were fitted over the ticks' mouth parts, the tubes were filled with glycine with these pipettes.

Since 1t was necessary to keep the ticks isolated on the rabbit, plastic capsules were prepared, using a modification of a method described by Jellison and Philip (1933). Square, transparent plastic boxes measuring $4.5 \times 4.5 \times 1.5$ cm. with covers were chosen. The bottom of the box was cut out. Flanges of light plastic cloth were glued to the outside of the box. The flanges were placed in between two strips of four-inch adhesive tape. The plece of tape near the body of the animal was just long enough to entirely oncirole the mid-region between the arm pits and hips of the rabbit (see figure 1). Dupont cement was applied to the stichy side of the tape to ensure a firmer attachment of the tape to the capsule. The rabbit was olosely elippod over this region, and the band was affixed to the rabbit. Care was taken that the band fit snugly but did not interfere with the activity of the rabbit. The capsules were covered with adhesive tape to protect them from being gnawed by the rabbit. The ticks were then placed in the capsule.

The Gelger-Yuller counter and the proportional flow counter were used to detect the radioactivity in counts per 


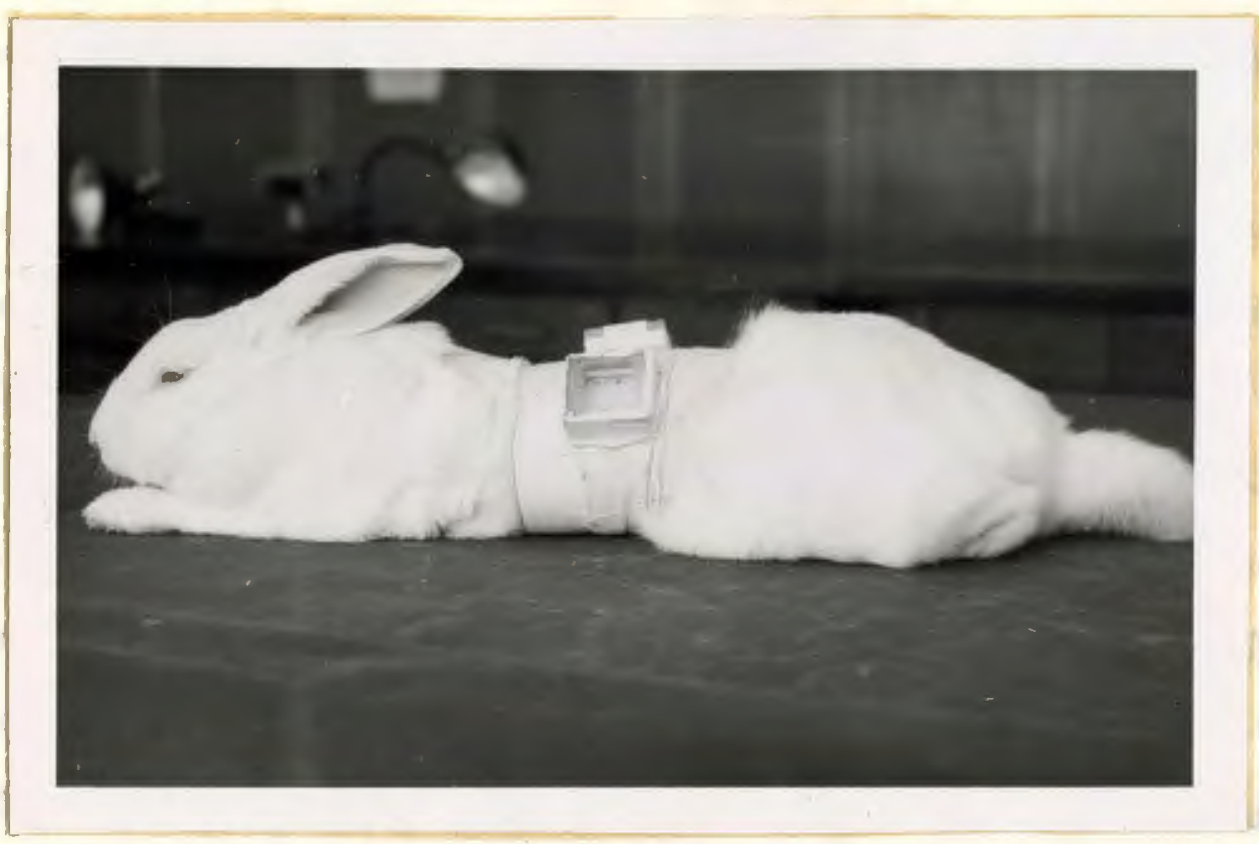

Figure la

Rabbit with capsules for engorgement of ticks.

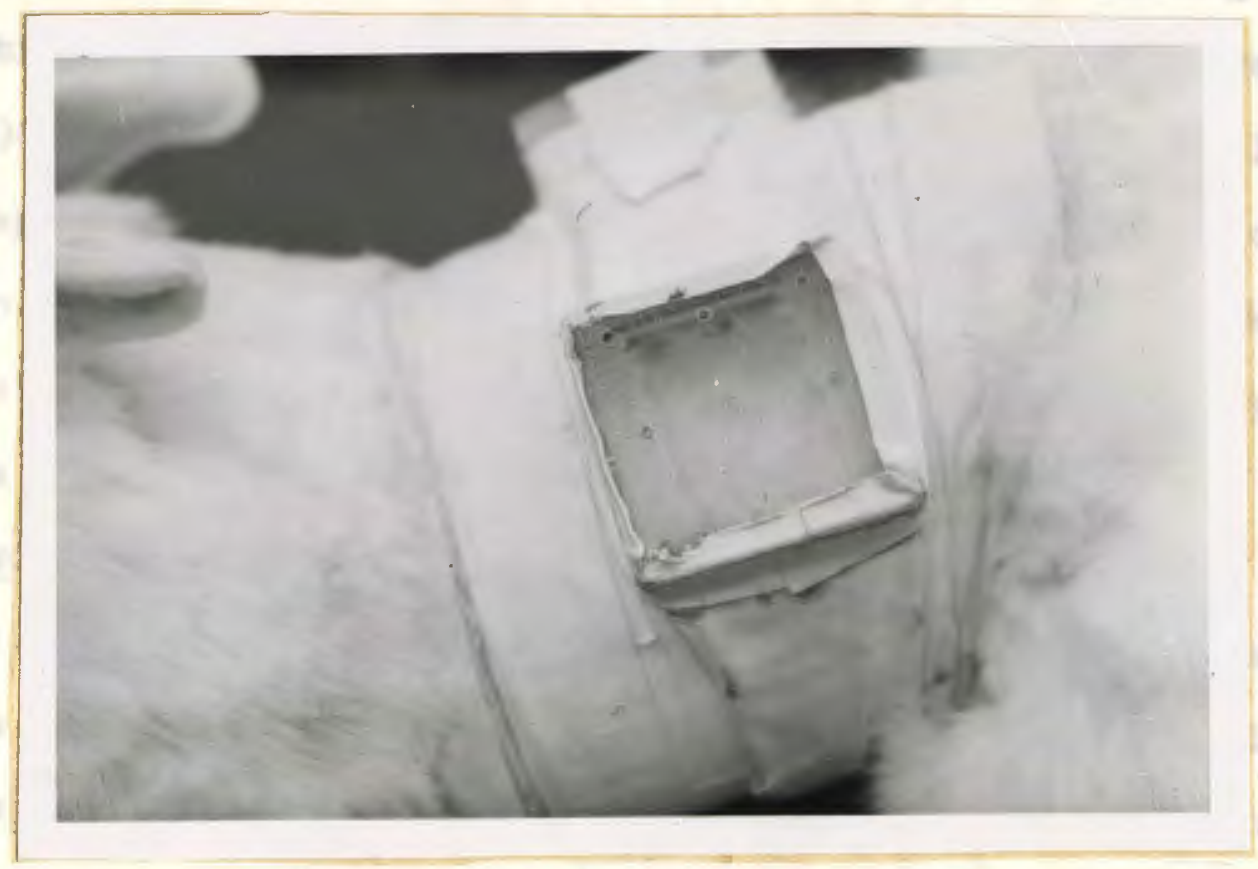

Figure lb

Close-up of capsule for engorgement of ticks on rabbit. 
minute. The Geiger-Muller counter, model 410, was manufactured by the Baird Atomic Instrument Company, Cambridge, Massachusetts. The tube was equipped with a mica window $1.43 \mathrm{mg}$. per $\mathrm{cm}{ }^{2}$ thick. This instrument was used to detect radiations from wholo adult ticks and was used for monitoring purposes.

The proportional flow counter was composed of three major parts: a windowless flow counter, manufactured by Packard Instrument Company, a preamplifier, model 255, and a scaler, model 1283. The last two parts were manufactured by Baird Atomic Instrument Company. Materlal to be counted was macerated in metal planchets with distilled water added and left to drs at room temperature. The planchets were then placed in the windowless flow counter. The counting gas was methane, and counting was done in the proportional region at 3700 volts. Since counts were obtalned from material prepared in two different ways, and the sensitivity of the two instruments were different, the results of the two machines could not be compared or correlated directly under the conditions of the investigation.

Administering the Isotope

Female ticks in lots of 10 were fed. Plasticine or clay was spread on a microscope slide, and a tick, ventral side up, was pressed into the plasticine. All but the front pair of legs were spread out and immobilized with small pleces of the plasticine. Care was taken not to cover the spiracles. A roll of plasticine was placed lengthwise on the slide near 
the tick's mouth parts, to function as a plllow or support for the feeding tubes. Three female ticks were applied to each slide. A feeding tube was inserted over the hypostome and chelicerae of each tick leaving the palps outside the pipette (see flgure 2.). Some radioactive material was removed from the serum bottle with a hypodermic syringe, and placed in a small beaker provided with a cover of adhesive tape to reduce evaporation from convection currents. The isotope was then taken up with a Pasteur pipette and delivered to the foeding tube. Another lot of ticks was fed control gljcine. The control and experimental ticks were kept separate in glass covered dessicator-type jars provided with damp toweling.

Several unfed controls chosen at random were tested for radioactivity. The counts per minute obtained were the same as the background count.

When the control ticks had finished the glyeine, they were placed in the previously prepared capsule on a rabbit for engorgement. Most rabbits had two capsules, a control one and an experimental one. Adult white rabbits weighing between five and elght pounds were employed. Determination of Radioactivity

When the experimental tick had finished foeding on the radioactive glycine, it was washed several times with water to remove any gljcine that had leaked from the foeding tube and dried on the mouth parts. The tick was allowed to airdry. Then 1t was placed under the Gelger-Muller tube in a 


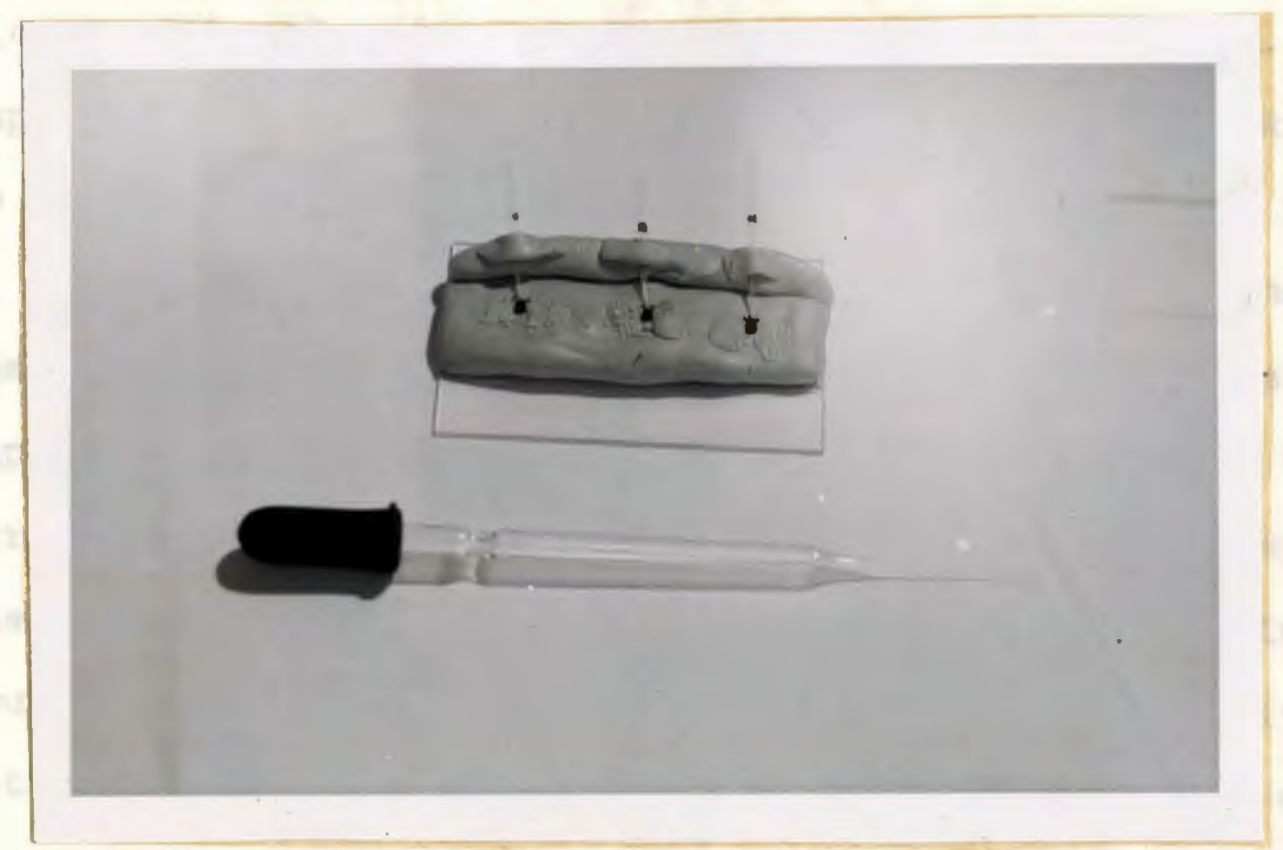

Figure 2

Set-up for feeding $\mathrm{C}^{14}$ glycine to female ticks. Shown in the photograph are three ticks imbedded in plasticine on a microscope slide. Also shown are the feoding tubes with one cm. calibration marks. Note, the drawn out Pasteur pipette in the foreground. 
planchet to measure radioactivity. The bottom of the planchet contained plasticine into which the legs were partially immoblized. The count of the tick, corrected for background count, was recorded. Then the ticks were placed with males in the plastic capsule on a rabbit. Capsules were examined frequently to remove dead ticks and to see that the capsule did not become chewed by the rabbit. When the females had fully ongorged, they dotached from the rabblt and were found actively walking around inside the capsule. These ticks were removed. The radioactive ticks were placed underneath the Gelger-Muller tube to determine their radioactivity. Each tick was placed, after being counted, In a cotton stoppered shell vial for oviposition. Both control and experimental vials were placed in a covered glass incubation jar containing damp sand and stored in the laboratory. Vials were checked periodically to determine the boginning of $\mathrm{gg}$ laying. The eggs developed at room temperature, which varied from $65^{\circ} \mathrm{F}$. at night to $70-80^{\circ} \mathrm{F}$. in the day. When temperatures became higher, the jar was moved to a cooler part of the bullding.

Before the eggs hatched lots of 200 eggs per tick were placed in a planchet and tested for radioactivity in the proportional flow counter. This was done for each experimental tick and for a fow controls. Lots of 200 larvae per tick were also treated in the same manner. Readings were made for a period of five minutes for each sample. Results were expressed in counts per minute, and were corrected for 
background count.

To ascertain where losses in radioactivity might occur other than through egg laying, a few readings were recorded for the feces of the engorging ticks and for crushed egg shells.

Determination of Egg Production and Hatchability

Before the eggs batched, they were counted at frequent intervals. The eggs were placed in a petri dish over a $3 \times 5$ file card containing marked off squares. With the ald of a dissecting microscope and a hand tally counter, the eggs were counted individually and then placed in a separate shell vial. The two vials, one holding the counted eggs and the other holding the female tick, were kept together with an elastic band and returned to the covered incubation jar. Fach time a group of eggs was collected from the tick and counted, the eggs were added to the separate vial of counted eggs. In this way no lot of eggs was counted twice. After hatehing had been taking place for about two weeks, the larvae were killed and the unhatched eggs counted. The ratio of eggs hatched to eggs lald was multiplied by 100 to determine the percentage of hatohability. 


\section{RESULTS}

Forty-one female ticks were fed with carbon-14 labeled glycine, and 40 were fed with unlabeled glycine. There were four lots of experimentals and four lots of controls fed. In each group a total of 36 females was placed on the hosts. (See table 1.) of these, 17 engorged control ticks and 14 engorged experimental ticks were recovered. The recovery for all ticks in the control group averaged 45 per cent. Mortality was high in both groups, amounting to 57 per cent for the control group and 65 per cent for the experimental group.

Before placing a female tick fed with carbon-14 glycine on the rabbit, a count of radioactivity was recorded with the Gelger-Muller tube and corrected for background count. The four lots fod gave averages of $222,1024,665$, and 1075 counts per minute. (See table 2.) It can be noted that there is variability in the value for the standard deviation as well as for the mean value for the initial radioactivity of the adults. Apparently females did not receive the same amounts of carbon-14 glycine during the feeding. When a female was recovered from the host, it was again tested for radioactivity. (See table 3.) Counts, when corrected for background, ranged from 87 to 450 per minute. The mean was 


\section{Table 1}

Total Number of Female Ticks of the Genus Dermecentor Fed with Control Glyeine and with C14 Glycine, Fer Cent Recovery from Host, and Per Cent Total Mortality for Each of F1ve Groups.

\begin{tabular}{|c|c|c|c|c|c|c|c|c|c|c|}
\hline \multirow{2}{*}{$\begin{array}{l}\text { Group } \\
\text { No. }\end{array}$} & \multicolumn{2}{|c|}{$\begin{array}{c}\text { No. Tleks } \\
\text { Fed }\end{array}$} & \multicolumn{2}{|c|}{$\begin{array}{l}\text { No. Ticks } \\
\text { on Rabbit }\end{array}$} & \multicolumn{2}{|c|}{$\begin{array}{l}\text { No. Tieks } \\
\text { Recovered }\end{array}$} & \multicolumn{2}{|c|}{$\begin{array}{l}\text { Per Cent } \\
\text { Recovery }\end{array}$} & \multicolumn{2}{|c|}{$\begin{array}{l}\text { Per Cent } \\
\text { Mortall ty }\end{array}$} \\
\hline & $\bar{c}$ & $E$ & $\bar{c}$ & $E$ & $\mathrm{C}$ & $\mathbf{E}$ & $c$ & $\mathbf{E}$ & $\bar{c}$ & $\mathbf{E}$ \\
\hline 1 & 10 & -- & 6 & -- & 2 & -- & 33 & -- & 80 & -- \\
\hline 2 & 10 & 10 & 10 & 9 & 6 & 4 & 60 & 44 & 40 & 60 \\
\hline 3 & $-\infty$ & 11 & - & 7 & $-\infty$ & 2 & - & 28 & -- & 81 \\
\hline 4 & 10 & 10 & 10 & 10 & 2 & 4 & 20 & 40 & 80 & 60 \\
\hline $5^{+}$ & 10 & 10 & 10 & 10 & 7 & 4 & 70 & 40 & 30 & 60 \\
\hline Total & 40 & 41 & 36 & 36 & 17 & 14 & & & & \\
\hline
\end{tabular}

Mean per cent recovery : control group ......... 45 Mean per cent recovery: : experimental group ...... 38

Mean per cent total mortality : control group .... 57 Mean per cent total mortality : experimental group 65

*C refers to data from control group.

E refers to data from experimental group.

tricks from group 5 belong to Dermacentor variabil1s. The remaining ticks bolong to Dermacentor andersoni. 


\section{Table 2}

Radloactivity in Counts Per Minute of Unengorged Females of the Genus Dermacentor Fed with CI4 Glycine.

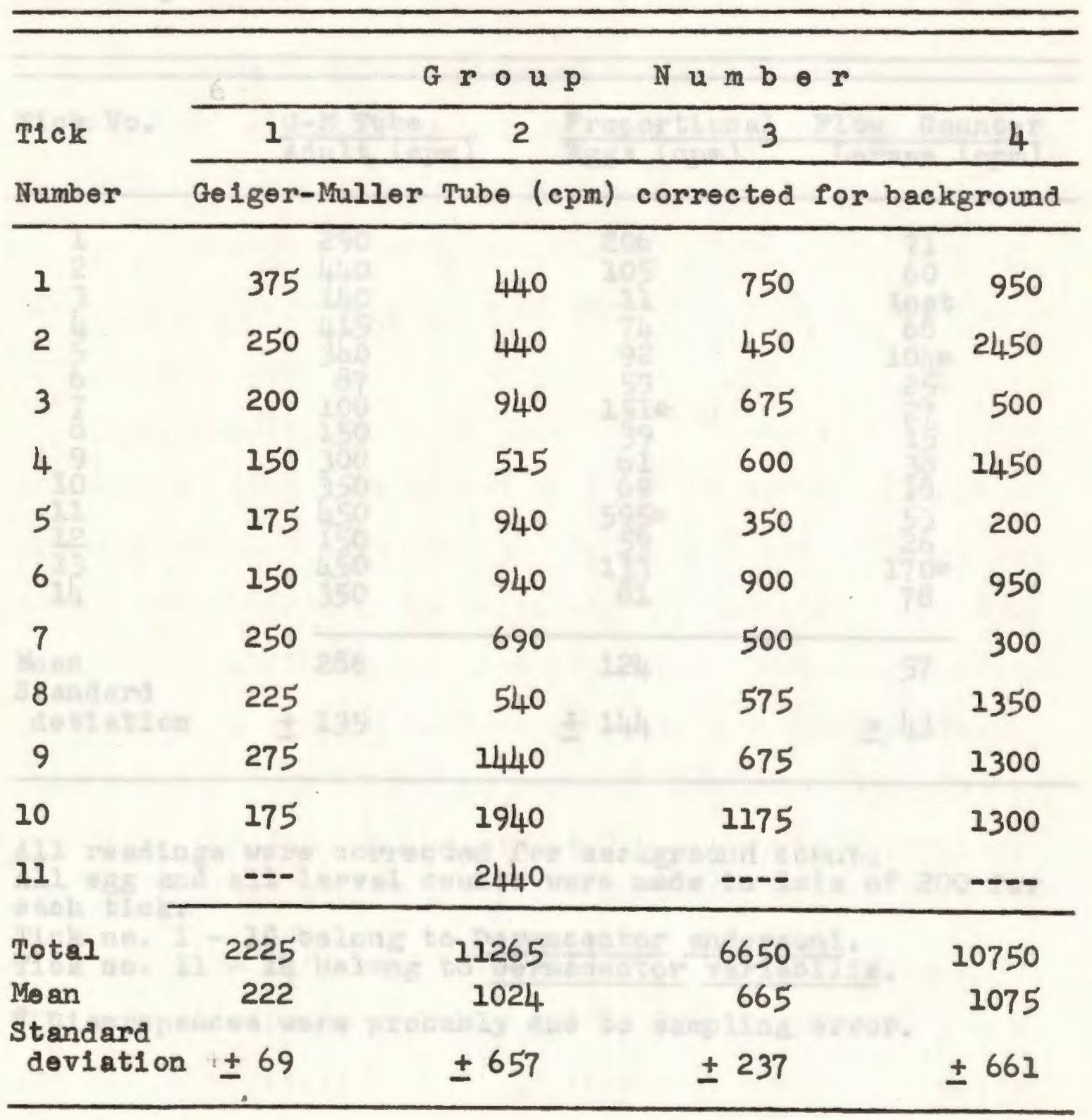

Ticks in groups 1 - 3 belong to Dermacentor andersoni. Ticks in group 4 bolong to Dermacentor variabilis. 


\section{Table 3}

Radioactivity in Counts Per Minute of Females of the Genus Dermacentor Recovered After Feeding with $\mathrm{C}^{4} 4$ Glycine and Engorgement on Host; Radioactivity of Eggs Lald and of Resulting Larvae.

T1ck No. $\quad \frac{\text { G-M Tube }}{\text { Adult (cpm) }} \quad \frac{\text { Proportional Flow Counter }}{\text { Eggs (cpm) Larvae (cpm) }}$

\begin{tabular}{cccc}
\hline 1 & 290 & 206 & 71 \\
2 & 440 & 105 & 60 \\
3 & 140 & 11 & $108 t$ \\
4 & 415 & 74 & 68 \\
5 & 340 & 92 & $104 \%$ \\
6 & 87 & 59 & 25 \\
7 & 100 & $151 \%$ & 27 \\
8 & 150 & 39 & 15 \\
9 & 300 & 61 & 38 \\
10 & 350 & $59 \%$ & 58 \\
11 & 450 & 59 & 26 \\
12 & 150 & 133 & $170 \%$ \\
13 & 450 & 81 & 78 \\
14 & 350 & 124 & 57 \\
Mean & 286 & \pm 144 & \pm 43 \\
Standard & \pm 135 & & \\
deviation & \pm & & \\
\hline
\end{tabular}

All readings were corrected for background count. All $\mathrm{gg}$ and all larval counts were made in lots of 200 for each tick. T1ck no. 1 - 10 belong to Dermacentor anderson 1. Tick no. 11 - 14 belong to Dermacentor variabilis. * Discrepances were probably due to sampling error. 
286 counts per minute, with a standard deviation of \pm 135 counts per minute. The resulting eggs, in lots of 200 each, gave counts ranging from 11 to 206 per minute. The moan was 124 counts per minute, with a standard deviation of \pm 144 counts per minute. Radioactivity in the larvae was less, with a mean of 57 counts per minute and a standard deviation of \pm 43 counts per minute.

The feces from one group of engorged ticks were measured with the Gelger-Muller tube, and were found to possess an activity of approximately 2500 counts per minute. Two masses of egg shells gave counts of 28 and 78 per minute when measured with the proportional counter and corrected for background count.

When the females were placed on the hosts, a record of the time taken to attach and engorge was made. The time after detachment from the host and the laying of the first eggs (pre-oviposition period), and the time until hatching (incubation period) were also recorded. There is a striking similarity in results between controls and experimentals. (See table 4.) Differences between mean days varied by a fraction, for days on the host and pre-ovipositon perfod, and only by two days for the incubation period. The data for the two species were kept separate with regard to egg production and hatchability. (See tables 5 and 6.) The individuals of D. andersoni controls produced a mean number of eggs of 6959 per tick. The experimentals la1d about 2000 eggs per tick less. W1th regard to D. 
Table 4

Period of Engorgement and Preoviposition Perlod of Recovered Females, and Incubation Perip of Eggs from Ticks of the Genus Dermacentor Fed with Cl4 Glycine and with Control Glyoine.

\begin{tabular}{|c|c|c|c|c|c|c|c|c|}
\hline \multicolumn{2}{|c|}{ Tlck No. } & & \multicolumn{2}{|c|}{$\begin{array}{l}\text { Engorgement } \\
\text { Perigd } \\
\text { (deys) } \\
\end{array}$} & \multicolumn{2}{|c|}{$\begin{array}{c}\text { Prooviposition } \\
\text { Period } \\
\text { (ders } \\
\end{array}$} & \multicolumn{2}{|c|}{$\begin{array}{c}\text { Incubation } \\
\text { Poriod } \\
\text { (davs) } \\
\end{array}$} \\
\hline${ }^{*} \mathrm{C}$ & $\mathbf{E}$ & & C & $\mathbf{E}$ & C & E & C & $\mathbf{E}$ \\
\hline 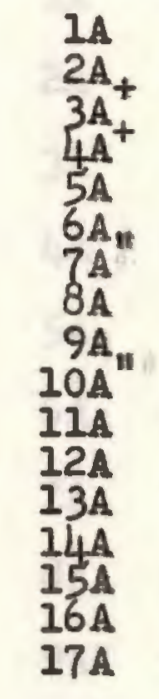 & $\begin{array}{c}1 \\
2 \\
3 \\
4+ \\
4^{+} \\
6 \\
7 \\
8 \\
9 \\
10 \\
11 \\
12 \\
13 \\
14 \\
-- \\
-- \\
--\end{array}$ & & $\begin{array}{r}12 \\
13 \\
12 \\
12 \\
12 \\
12 \\
12 \\
13 \\
15 \\
19 \\
9 \\
9 \\
11 \\
11 \\
11 \\
14 \\
14\end{array}$ & $\begin{array}{l}11 \\
11 \\
12 \\
12 \\
9 \\
10 \\
11 \\
12 \\
12 \\
24 \\
11 \\
11 \\
13 \\
14 \\
-- \\
-- \\
--\end{array}$ & $\begin{array}{r}8 \\
9 \\
4 \\
18 \\
6 \\
4 \\
-4 \\
4 \\
3 \\
-5 \\
5 \\
5 \\
4 \\
6 \\
7 \\
2 \\
5\end{array}$ & $\begin{array}{r}4 \\
3 \\
3 \\
17 \\
10 \\
5 \\
5 \\
4 \\
4 \\
5 \\
8 \\
3 \\
6 \\
1 \\
\hdashline- \\
\hdashline-\end{array}$ & $\begin{array}{l}32 \\
28 \\
-- \\
-5 \\
28 \\
30 \\
--5 \\
31 \\
24 \\
--0 \\
35 \\
32 \\
34 \\
34 \\
33 \\
35 \\
32\end{array}$ & $\begin{array}{l}28 \\
28 \\
28 \\
-- \\
-- \\
32 \\
23 \\
25 \\
25 \\
31 \\
32 \\
37 \\
32 \\
33 \\
-- \\
--\end{array}$ \\
\hline \multicolumn{2}{|c|}{$\begin{array}{l}\text { Mean } \\
\text { Standard } \\
\text { deviation }\end{array}$} & & $\begin{array}{r}12 . \\
\pm 2\end{array}$ & $\begin{array}{r}12.3 \\
\pm \quad 3.5\end{array}$ & \pm 3.7 & $\begin{array}{r}5.5 \\
\pm \quad 3.9\end{array}$ & $\begin{array}{r}31.3 \\
\pm 3.1\end{array}$ & $\begin{array}{r}29.5 \\
\pm \quad 4.1\end{array}$ \\
\hline
\end{tabular}

*C refers to data from control group.

E refers to data from experimental group.

Hatching was low and the beginnings of hatching were not nobserved.

Females did not produce eggs. 
Table 5

Egg Production and Hatchablifty Data for Dermacentor andersoni Females Fed with Control Gljeine and with $\mathrm{C}^{14}$ GIJcine.

\begin{tabular}{|c|c|c|c|c|c|c|c|}
\hline \multicolumn{2}{|c|}{ Tick No. } & \multicolumn{2}{|c|}{ No. Eggs Laid } & \multicolumn{2}{|c|}{$\begin{array}{l}\text { No. Eggs } \\
\text { Hatched }\end{array}$} & \multicolumn{2}{|c|}{$\begin{array}{l}\text { Per Cent } \\
\text { Hatchabill ty }\end{array}$} \\
\hline$\overline{\# C}$ & $E$ & $\bar{c}$ & $\mathrm{E}$ & $\bar{c}$ & $E$ & $\bar{c}$ & $\mathbf{E}$ \\
\hline $1 \mathrm{~A}$ & 1 & 7742 & 3976 & 7186 & 3504 & 92.8 & 88.1 \\
\hline $2 \mathrm{~A}$ & 2 & 8146 & 6990 & 4288 & 6243 & 52.6 & 89.3 \\
\hline $3 A^{+}$ & 3 & 8638 & 6479 & $(243)$ & 5874 & $(2.8)$ & 90.6 \\
\hline $4 A$ & 4 & 163 & 1246 & 101 & 228 & 61.9 & 18.3 \\
\hline $5 A$ & 5 & 8294 & 627 & 7719 & 111 & 93.0 & $17 \cdot 7$ \\
\hline $6 A$ & 6 & 6431 & 3396 & 4190 & 2086 & 65.1 & 61.4 \\
\hline $7 A^{\prime \prime}$ & 7 & $-\ldots$ & 6617 & $-\infty-\infty$ & 5484 & ---- & 82.8 \\
\hline $8 \mathrm{~A}$ & 8 & 10327 & 5341 & 9574 & 4995 & 92.7 & 91.8 \\
\hline $9 A$ & 9 & 5937 & 6693 & 5654 & 6495 & 95.2 & 96.5 \\
\hline $10 A^{n}$ & 10 & $-\cdots$ & 5603 & - & 1762 & $-\ldots$ & 31.4 \\
\hline \multicolumn{2}{|c|}{ Total } & 55678 & 46968 & 38712 & 36636 & & \\
\hline \multicolumn{2}{|c|}{ Me an } & 6959 & 4696 & 5530 & 3663 & 79.0 & 66.7 \\
\hline \multicolumn{2}{|c|}{$\begin{array}{l}\text { Standard } \\
\text { deviatiol }\end{array}$} & \pm 3058 & 2310 & 3074 & 2464 & & \\
\hline
\end{tabular}

* C refers to data from control group.

E refers to data from experimental group.

+No. eggs hatched and per cent hatchability are not included uin total data. Eggs were attacked by mold after being laid. "Females did not produce eggs. 
Table 6

Egg Production and Hatchabli1ty Data for Dermacentor variabilis Females Fed with Control Glycine and with cl4 GIgeIne.

\begin{tabular}{|c|c|c|c|c|c|c|c|}
\hline \multicolumn{2}{|c|}{ Tick No. } & \multicolumn{2}{|c|}{ No. Eggs Laid } & \multicolumn{2}{|c|}{$\begin{array}{l}\text { No. Eggs } \\
\text { Hatched }\end{array}$} & \multicolumn{2}{|c|}{$\begin{array}{l}\text { Per Cent } \\
\text { Hatchability }\end{array}$} \\
\hline${ }^{*} \mathrm{C}$ & $\mathbf{E}$ & C & $E$ & C & $\mathbf{E}$ & c & $\mathrm{E}$ \\
\hline $11 \mathrm{~A}$ & 11 & 4083 & 2646 & 3927 & 2562 & 96.1 & 96.8 \\
\hline $12 \mathrm{~A}$ & 12 & 3284 & 1571 & 3183 & 1494 & 96.9 & 95.1 \\
\hline $13 A$ & 13 & 2343 & 1143 & 2292 & 1119 & 97.8 & 97.9 \\
\hline $14 \mathrm{~A}$ & 14 & 2111 & 2786 & 2002 & 2491 & 94.8 & 89.4 \\
\hline $15 \mathrm{~A}$ & -- & 3025 & $-\infty-$ & 2849 & --- & 94.1 & $-\infty-$ \\
\hline $16 A$ & -- & 5291 & $-\infty-$ & 4967 & $-\cdots-$ & 93.8 & $-\cdots$ \\
\hline $17 \mathrm{~A}$ & -- & 1622 & -..- & 1559 & --- & 96.1 & ---- \\
\hline \multicolumn{2}{|c|}{ Total } & 21759 & 8146 & 20779 & 7666 & & \\
\hline \multicolumn{2}{|c|}{ Me an } & 3108 & 2036 & 2968 & 1916 & 95.6 & 94.8 \\
\hline \multicolumn{4}{|c|}{$\begin{array}{l}\text { Standard } \\
\text { deviation } \pm 1261\end{array}$} & \pm 1179 & \pm 721 & & \\
\hline
\end{tabular}

* C refers to data from control group.

E refers to data from experimental group. 
varlabilis the controls lald an average of 3108 eggs per t1ck and the experimentals an average of 2036 eggs. This represents a difference of about 1000 eggs. Again the average varled by approximately 1000 for controls and experimentals in numbers of eggs hatched per t1ck.

To determine whether there was a signiflcant difference between experimental and control groups, with regard to the number of eggs la1d and the number of eggs hatched, an F test for testing differences between varlances and a " $t$ " test for testing differences botween means was carried out. (See tables 7 and 8.) There was no signiflcant difference between the two groups with respect to the variables-number of eggs laid and number of eggs hatehed. 


\section{Table 7}

F Values Testing Differences in Varlances Between Control and Experimental Groups of Dermacentor andersonl and Dermacentor variabilis.

\begin{tabular}{|c|c|c|c|c|c|}
\hline$F$ & Value & de & $\begin{array}{c}\text { Confidence } \\
\text { Level }\end{array}$ & $\begin{array}{l}\text { Computed } \\
\text { F Value }\end{array}$ & $\begin{array}{l}\text { To Test Differ- } \\
\text { ences Between }\end{array}$ \\
\hline & 3.29 & 7.9 & .95 & 1.7 & $\begin{array}{l}\text { eggs laid-- } \\
\text { D. andersonl } \\
\text { control and } \\
\text { experimental }\end{array}$ \\
\hline & $3 \cdot 37$ & 6,9 & .95 & 1.5 & $\begin{array}{l}\text { eggs hatched-- } \\
\text { D. andersonl } \\
\text { control and } \\
\text { experimental }\end{array}$ \\
\hline & 8.94 & 6,3 & .95 & 2.4 & $\begin{array}{l}\text { eggs laid-. } \\
\text { D. variabli1s } \\
\text { control and } \\
\text { experimental }\end{array}$ \\
\hline & 8.94 & 6,3 & .95 & 2.6 & $\begin{array}{l}\text { eggs hatched-- } \\
\text { D. variabli1s } \\
\text { control and } \\
\text { experimental }\end{array}$ \\
\hline
\end{tabular}


Table 8

"t" Values Testing Differences in Means Between Control and Experimental Groups of Dermacentor anderson1 and Dermacentor variab1lis.

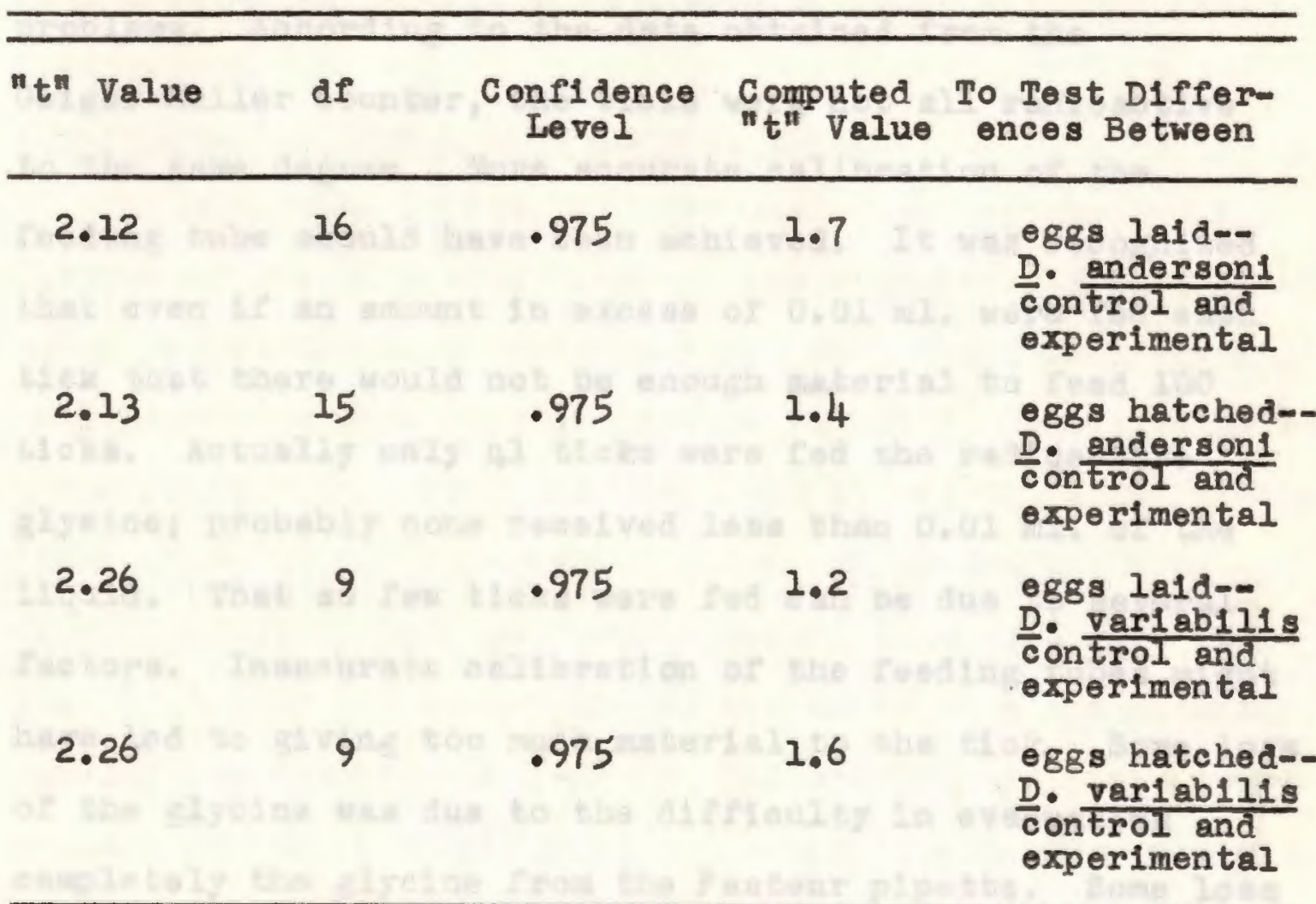




\section{DISCUSSI ON}

Problems in Administering the Isotope

The feeding technique exployed presented certain problems. According to the data obtained from the Geiger-Muller counter, the ticks were not all radioactive to the same degree. More accurate calibration of the feeding tube should have been achieved. It was recognized that even if an amount in excess of $0.01 \mathrm{ml}$. were fed each tick that there would not be enough material to feed 100 ticks. Actually only $4 \mathrm{l}$ ticks were fed the radioactive glycine; probably none received less than $0.01 \mathrm{ml}$. of the 11quid. That so few ticks were fed can be due to several factors. Inaccurate calibration of the feeding tubes might have led to giving too much material to the tick. Some loss of the glycine was due to the diffculty in evacuating completely the glycine from the Pasteur pipette. Some loss probably occurred through evaporation when the 1sotope was placed into the beaker even though the latter was covered. Problem of Low Recovery of Ticks

More engorged ticks should have been recovered from the rabb1ts. Kohls (1937) gives some recovery data for ticks under mass rearing conditions, but statistics are not available for survival of engorged adults. However, a mortality greater than 50 per cent for adults should be 
questioned. Perhaps when the Dupont cement was applied to the tape on the plastic capsule, the cement did not dry quickly enough, and some of the solvents in the cement may have permeated the capsule and killed the ticks. However, the capsules were generally applied to the rabbit at least several hours before the ticks were introduced. Some of the chemicals in the cement of the adhesive tape may have boen deleterious.

Limitations on Number of Engorging Ticks

No more than 20 females were placed on any one rabblt because of the danger of anemia. Experiments by Jellison and Kohls (1938) Indicate that secondary anemia can be Induced on rabbits having more than 60 females attached. Since males do not engorge much, their presence, within reason, is of little consequence as far as exsanguination and anemia are concerned. Rabbits were not used a second time as hosts. Work done by Trager (1939a and 1939b) indicates that the rabbit develops an immunity to repeated infestations of ticks over a short period of time. Although Trager's work was done with larvae and nymph as the second infesting animal, it was expected at this time that there might be a possibility of the rabbit developing a reaction to the bite of a second group of adult ticks.

Difference in Egg Production Between D. Variabilis and D. andersont

According to several investigators the number of eggs laid per tick for both species is similar. Bishopp and Smith 
(1938) state a range for D. variab111s of 4,000 to 6,500 eggs per tick. Kohls (1937) found that $\underline{D}$. andersont females laid 4,000 to 7,000 eggs per tick. From the present investigation the mean number of eggs deposited by D. andersoni fell within the range mentioned. (See table 5.) However, the mean number of eggs produced by D. variabilis females fell below the range quoted by Bishopp and Smlth (1938). (See table 6.) Controls produced a mean of 3108 eggs per tick, and the experimentals deposited slightly less--2036 eggs per tick. The reason for this lowered production is not known. Two possible explanations are offered. The D. Variabilis adults still might have been relatively unready to feed, and the storage of ticks for several months in the pill boxes might have reduced them to a poorer condition than the $D$. andersoni which were used within three months after shipment. It was noted that the ticks seemed to engorge not as fully as did $\underline{D}$. andersoni. Analysis of the Data

Although the focus of the investigation was of a qualitative nature, in order to ascertain some of the effects of the 1sotope, it was necessary to collect quantitative data. In order to interpret this data, statistical methods of analysis had to be employed. Average or mean values for each category, such as number of eggs laid or the length of the incubation period, were determined. It was also meaningful to obtain some quantitative measure of variation about the mean. One such measure is known as standard deviation 
(Dixon and Massey, 1957, p. 18). One standard deviation on either side of the mean embraces 68.27 per cent of the total values represented under the normal curve; two standard deviations on either side of the mean includes 95.45 per cent; and three standard deviations on elther side of the mean covers 99.7 per cent. The larger the standard deviation, the larger the variation in the particular group concerned. At first the values for eggs lald and eggs hatched were analyzed statistically without separation of the two species. Further examination of the data (see tables 5 and 6) revealed that in D. variabilis the females laid only half as many eggs as did those of $\underline{D}$. andersoni. It seemed apparent that as far as the egg laying was concerned, two different populations were being treated. It was important to establish this as a real difference and not one due to random sampling in order to analyze the effect of radioactivity on egg laying and egg hatching.

Since the square of the standard deviation, the variance, is an estimate of the population variance, and since the arithmetic average is an estimate of central tendency of the population, differences in either of these estimates would suggest that the samples are derived from different populations.

A statistical test called the $F$ test was conducted on the controls of the two species. This test is designed to indicate significant differences in variances between two populations (Dixon and Massey, 1957, p. 102). The statistic 
$F$ given by the formula $F=\frac{s_{1}^{2}}{s_{\alpha}^{2}}$ with $\left(n_{1}, n_{2}\right)$ degrees of freedom where $s_{1}^{2}$ equals the sample variance of the population, has a sampling distribution called the F distribution. Tables of values have been computed for certain degrees of freedom and certain percentiles for the $F$ distribution (Dixon and Massey, 1957, p. 300). Thus, if a value is tabled at the 95 per cent level of confidence, there will be a five per cent chance that an F value computed from experimental data will be larger than the value given. When the $F$ value was computed for the eggs lald, for all the controls, the value was 5.88. When the table was consulted at 6,7 degrees of freedom at the 95 per cent confidence level, the F value was found to be 4.21 . This is smaller than the $F$ value computed from the data. Since this is the case, the hypothesis of no differences between the variances of the populations is rejected.

Similar results were obtained when the F test was applied to test for significant differences in egg hatching between the two species in the control ticks. The F value given in the table was 4.28 at 6 degrees of freedom for the denominator as well as for the numerator, at a confidence level of 95 per cent. Since the computed $F$ value was even larger-- 6.07 --, there was also a significant difference in variances in egg hatching between the two species. On the basis of these results the two species were separated into two distinct populations experimentally and analyzed apart. 
The F values for measuring differences between controls and experimentals of $\mathrm{D}$. andersoni were computed. (See table 7.) When these were compared with the values derived from the table of percentiles of the F distribution, they were smaller than the values obtained from the table. Furthermore, when an examination of the remainder of table 7 was made, 1t was found that all the computed $F$ values at the 95 per cent level of significance were smaller than the given $F$ values. Therefore, there was no significant difference in variances within any one species between experimentals and controls with respect to eggs laid and eggs hatched.

One cannot assume there is no difference between the experimental and control groups within a species even though the variances are statistically non-significantly different. There may exist differences between means. Therefore, the " $t$ " test was conducted to test the hypothesis that no significant difference exists between the sample means. A table of the percentiles of the "t" distribution has been compiled ( $D 1 x$ an and Massey, 1957, p. 384). If values computed from the data are smaller than values represented in the " $t$ " table, then there is no significant difference between the means of the two groups. The samples are then assumed to have come from the same population. The results of the " $t$ " test are shown in table 8 . There are no significant differences between the average number of eggs laid and the average number of eggs hatched, between the experimental and control groups, within D. variabilis 
and $\underline{D}$. anderson 1 .

Since both tests for variability not produoed as a result of natural variation prove to be non-significant, it can be concluded that there is no effect of radioactivity on the fecundity and hatchability of eggs laid by the experimentals of adult females within D. andersoni and $D$. variabilis. Whether the radioactivity might affect a later part of the life cycle is not known. It may have an effect on the attachment and engorgement of the larvae or subsequent stages. There is the possibility that the engorged larvae may experience difficulty during ecdysis. It is not known whether the radioactivity might have produced a visible mutation, since the larvee were not mounted on slides and examined.

Suggested Uses of the Feeding Tochnique

The micropipette method of feeding lends itself easily to the administering of liquids to certain kinds of arthropods. Some of the chewing insects, such as cockroaches and boetles, may be fed in this way. Ze1d, et al. (1953) used micropipettos to feed an insecticide dissolved In corn oll to cockroaches. The rate of flow of the corn 011 was regulated by means of a manual pipettor. Large Insects possessing the proper mouth parts could be easily labeled for field studies and physiological studies. Among the ticks, the character of the feeding process could be observed. In this way it could be shown whether the actual sucking of blood is a constant sucking or whether the 
sucking movement is actually accompanied by some regurgitation.

Use of the Isotope in the Fleld

From this investigation it has beon demonstrated that 1t is difficult to detect emissions from cll with the Gelger-Muller tube employed more than two or three inches from the radioactive tick. Since this is the case, the use of $\mathrm{c}^{14}$ in labeling ticks for field work is not considered very practical.

Fleld work in several phases of the life cjcle of the tick should be undertaken. These are the oviposition period, time spent in the varlous developmental stages, and the place of overwintering. When in any of these stages, the tick usually seoks a protected place and is difficult to locate. In order to estimate the length of the life cycle of the dog tick in Rhode Island, it 18 necessary to be able to trace all parts of the 11 fe cycle. By placing radioactive females into the field it would be possible to follow the life cycle through all 1 ts stages, assuming that a high level of radioactivity would be retained within the tick without adversely affecting 1ts biology.

Since $c^{14}$ is relatively easy to handle, it is hoped that a more sensitive detection instrument will be developed. 


\section{CONCLUSIONS}

It can be concluded from the results of this investigation that:

1. Females of Dermacentor andersoni and D. variab111s were made radioactive by feeding them carbon-14 labeled glyeine through microplpettes.

2. Transovarial passage of radioactivity from females fed carbon-14 was demonstrated. The degree of radloactivity was less for the larvae than the initial experimental females.

3. Radioactivity at the level of concentration administered had no ffect on fecundity and hatchability of the eggs.

4. Using the $F$ test a significant difference in number of eggs produced between the controls of Dermacentor variabilis and $D$. andersoni was demonstrated. 


\section{SUMMARY}

A method adapted for administering isotopes to arthropods has been reported. Adult females of Dermacentor variabllis and $D$. andersoni were fed approximately $0.01 \mathrm{ml}$. of glycine labeled with carbon-14 by means of feeding tubes which were fitted over the mouth parts of each tick. A similar number was fed unlabeled glycine. After the carbon-14 glgcine was imbibed, the tick was placed in a plastic capsule on a rabbit with male ticks and allowed to mate and engorge. When engorged the females were removed from the capsules and placed in vials for oviposition.

The mean counts of radioactivity for unengorged females varied from 222 to 1075 counts per minute as recorded by the Gelger-Muller counter. Engorged female adults had a mean count of 286 per minute. Eggs and larvae in lots of 200 gave average counts per minute of 124 (for the eggs) and 57 (for the larvae). Radioactivity had no aignificant effect on egg laying and egg hatching. Control females of both species lald slightly more oggs and had a slightly higher per cent hatchability than the experimentals. However, the difference was not great enough to be significant as determined by the F statistic. There was a reduction in egg laying of D. variabil1s controls and experimentals when compared with published figures. The reason for this 
is not known. Some loss in radioactivity occurred through excretion and in the egg shells. 


\section{ACKNOWLEDGEMENTS}

The writer 1s grateful to Dr. Kerwin E. Hyland of the Department of Zoology, University of Rhode Island, for his constant supervision and assistance during the investigation.

The writer wishes to thank Mr. Edward W. Underhill of the Department of Pharmacognosy, University of Rhode Island, for permission to use the radiation detection equipment, for his valuable suggestions and assistanoe in working with the isotope, and for oritically reading this manuscript.

To Dr. J. Steven Kahn of the Department of Geology, University of Rhode Island, the writer extends her thanks for his timely and prompt assistance in guiding the statistical analyses of the results of the investigation. She also wishes to thank him for his careful and critical reading of the manuscript.

Thanks should also go to Dr. Elmer A. Palmatier of the Department of Botany and Professor Robert A. DeWolf of the Department of Zoology, University of Rhode Island, for their critical reading of the manuscript.

The miter wishes to thank the Rocky Mountain Laboratory, Hamilton, Montana, for supplying the ticks. 


\section{IITERATURE CITED}

Bishopp, F. C. and C. N. Smith. 1938. The American dog tick, eastern carrier of Rocky Mountain spotted fever. 0. S. Dept. Agr. Cir. 478: 1-26.

Brooks, A. L. 1956. Radioisotopes in entomologJ.

Unpublished paper. 26 p.

Bruce-Chwatt, I. J. and J. Hayward. 1956. Uptake of radioactive phosphorus by larvae and adults of mosquitoes. Nature. $177(4510): 661-662$.

Buck, J. 1953. Physical properties and chemical composition of Insect blood. 174-176. In Roeder, K. D., ed. Insect Physiology. John Wiley and Sons, Inc., New York. $1100 \mathrm{p}$.

Bugher, J. 1955. Blological effects of radiation. In Proceedings of the international conference on the peaceful uses of atomic energy. 11: 45-48.

Bugher, J. C. and Marjorie Taylor. 1949. Radiophosphorus and radiostrontium in mosquitoos, preliminary report. Sc1ence. 110(2849): 146-147.

Bugher, J. C., Marjorie Taylor and I. T. Bruce-Chwatt. 1956. p. 505. In Bruce-Chwatt, I. T. Radiolsotopes for research on and control of mosquitoes. B. World Health Organ. 15(3-4-5): 491-511. 
Burgdorfer, Willy. 1957. Artificial feeding of lxodid ticks for studies on the transmission of disease agents. J. Infect. Dis. 100(3): 212-214.

Chabaud, A. G. 1950. Sur la nutrition artificielle des tiques. Ann. de Parasitol. 25(1-2): 42-47. Dixon, W. J. and F. J. Massey, Jr. 1957. Introduction to statistical analysis. 2nd od. Mc Graw-Hill Book Co., Inc., New York. 488 p.

Fang, S. C. and D. Allon. 1955. Distribution and incorporation of radioactive phosphorus in the Douglas-fir beetle. J. Econ. Ent. $48(1): 79-82$.

Fredeen, F. J., J. W. Spinks, J. R. Anderson, A. P. Arnason and J. G. Rempel. 1953. Mass tagging of black flies (Diptera: Simulildae) with radiophosphorus. Canad. J. 2001. 31(1): 1-15.

Fuller, R. A., P. W. Rlegert and J. W. Spinks. 1954. Persistence of radio-activity in grasshoppers (Acrididae) tagged with phosphorus-32. Canad. Ent. 86(5): 201-203. Fuller, R. A., J. W. Splnks, A. P. Arnason and H. MeDonald. 1950. The use of radio-active tracers in investigations on soll-1nhabiting insects. Annu. Rpt. Ent. Soc. Ontario. 81: 7-15.

Gray, R. 1952. Composition of honeydew excreted by pineapple mealy bugs. Sclence. 115(2980): 129-133. Gregson, J. D. 1956. The Ixodoldea of Canada. Canad. Dept. Agr., P. 930: 28-30. 
Hassett, C. C. and D. W. Jenkins. 1949. Production of radioactive mosquitoes. Science. 110(2848): 109-110. Hassett, C. C. and D. W. Jenkins. 1951. The uptake and effect of radiophosphorus in mosquitoos. Physiol. Z0o1. 24(3): 257-266. Hoffman, R. A., A. W. Lindquist and J. S. Butts. 1951. Studies on treatment of flies with radioactive phosphorus. J. Econ. Ent. 44(4): 471-473. Jellison, W. L. and G. M. Kohls. 1938. Tick-host anemia:

a secondary anemia induced by Dermacentor andersoni Stiles. J. Parasitol. 24(2): 143-154. Jellison, W. L. and C. B. Philip. 1933. Technique for routine and experimental feeding of certain Ixodid ticks on guinea pigs and rabbits. U. S. Pub. Health Serv. Rpt. 48(35): 1081-1082.

Jenkins, D. W. 1954. Advances in medical entomology using rad101 sotopes. Expt. Parasitol. 3(5): 474-490. Jenkins, D. W. and C. C. Hassett. 1950. Rad1oisotopes in entomology. Nucleonies. 6(3): 5-14. Jones, S. C. and L. Wallace. 1955. Cherry frult fly dispersion studies. J. Econ. Ent. 48(5): 616-617. Kartman, L. 1954. Studies on Pasteurella pestis in fleas. 1. An apparatus for the experimental feoding of floas. Expt. Parasitol. 3(6): 525-537. Knapp, S. E., C. J. Farinacc1, C. M. Herbert and E. L. Saenger. 1956. A method for labeling the lone star ticks with a radioactive indicator ( 32 ). J. Econ. 
Ent. $49(3):$ 393-395.

Kohls, G. M. 1937. Tick rearing methods with special reference to the Rocky Mountain wood tick, Dermacentor andersoni Stiles. 246-256. In Galtsoff, P., F. Iutz, P. Welch, J. Needham, ed. Culture methods for invertebrate animals. Comstock Publishing Co., Inc., New York. $590 \mathrm{p}$.

Lawson, F. R., G. B. Lucas and N. S. Hall. 1954. Translocation of radioactive phosphorus injected by the green peach aphid into tobacco plants. J. Econ. Ent. $47(5): 749-752$.

Lindquist, A. W. 1952. Radioactive materials in entomological research. J. Econ. Ent. 45(2): 264-270. Lindsay, E. and R. Craig. 1942. The distribution of radiophosphorus in wax moth, mealworm, cockroach, and firebrat. Ann. Ent. Soc. Amer. 35(1): 50-56.

Oertel, E., R. Emerson and H. Wheeler. 1953. Transfer of radioactivity from worker to dronehoney bees after ingestion of radioactive sucrose. Ann. Ent. Soc. Amer. $46(4): 596-598$.

Cughton, J. 1950. "Tagging" root maggot flies (Hylemya spp., Anthomyidae) by means of radioactive phosphorus. Annu. Rpt. Ent. Soc. Ontario. 81: 91-92.

Provost, M. 1952. The dispersal of Aedes taeniorhynchus.

I. preliminary studies. Mosquitor News. 12(3): 174-190. Quarterman, K. D., J. A. Jensen, W. Mathis and W. W. Smith. 1955. Flight dispersal of rice field mosquitoes in 
Arkansas. J. Econ. Ent. $48(1): 30-32$. Quarterman, K. D., W. Mathis and J. W. Kilpatrick. 1954.

Urban fly dispersal in the area of Savannah, Georgia.

J. Econ. Ent. 47(3): 405-412.

Radeleff, R. D., R. C. Bushland and D. E. Hopkins. 1952.

Phosphorus-32 labeling of the screw-worm fly. J. Econ.

Ent. 45(3): 509-514.

Richards, A. G. 1951. The integument of arthropods. 59-70.

University of Minnesota Press, Minneapolis. $411 \mathrm{p}$. Rodriguez, J. G. 1954. Radiophosphorus in metabolism

studies in the two spotted spider mite. J. Econ. Ent. $47(3): 514-517$.

Smith, C. N., M. M. Cole and H. K. Gouck. 1946. Biology and control of the American dog tick. U. S. Dept. Agr. Tech. B. 905.74 p.

Trager, W. 1939a. Acquired immunity to ticks. J. Parasitol. $25(1): 57-81$.

1939b. Further observations on acquired immunity

to the tick Dermacentor variabilis Say. J. Parasitol. 25(2): $137-139$.

Yates, W. W., C. M. Gjullin, A. W. Lindquist and J. A. Butts. 1951. Treatment of mosquito larvae and adults with radioactive phosphorus. J. Econ. Ent. $44(1): 34-37$. Zamecnik, P. C., R. B. Loftfield, Mary L. Stephenson and C. M. Williams, 1949. Blological synthesis of radioactive silk. Science. 109(2843): 624-626. 
Zeld, M. M., P. A. Dahm, R. E. Hein and R. H. Me Farland. 1953. Tissue distribution, excretion of $\mathrm{C}^{14} \mathrm{O}_{2}$ and degration of radioactive pyrethrins administered to the American cockroach. J. Econ. Ent. 46(2): 324-336. 